\title{
Corporate Governance and Book-Tax Differences: Tunisian Evidence
}

\author{
Wiem Dridi ${ }^{1} \&$ Adel Boubaker ${ }^{1}$ \\ ${ }^{1}$ Université de Tunis El Manar, Tunisia \\ Correspondence: Wiem Dridi, Université de Tunis El Manar, Tunisia. E-mail: wiembououni@gmail.com
}

Received: June 8, 2015

Accepted: December 16, 2015 Online Published: December 25, 2015

doi:10.5539/ijef.v8n1p171

URL: http://dx.doi.org/10.5539/ijef.v8n1p171

\begin{abstract}
This paper's main objective is to examine the effect of corporate governance on earnings manipulations using BTD proxy. We investigate whether ownership structure board and audit committee characters affect earnings and tax management. Based on a sample of 21 corporations listed on Tunisian stock market during the period 2003-2012, our study employs regression analysis to test the prediction that the governance attributes reduces the likelihood of earnings and tax aggressiveness. We find that the ownership structure is an important corporate governance mechanism that affects BTD. We find that BTD does not vary with board size and the cumulative effect of the function of chief executive and president of the board. We find that the percentage of outside directors is associated with managerial discretion. Finally, we find that the audit committee influences ABTD through the variable relating to the financial expertise of the committee.
\end{abstract}

Keywords: book-tax differences; ownership structure, board of directors, audit committee

\section{Introduction}

In recent years, Previous studies have confirmed the usefulness of book-tax differences (BTD) as an attribute of earnings quality (Hanlon, 2005; Blaylock et al., 2012; Dhaliwal et al., 2009; Goh et al., 2013, Hanlon et al., 2012, Joos et al., 2000; Mills \& Newberry, 2001; Donohoe \& McGill, 2010; Comprix et al., 2011, Tang \& Firth, 2011; Chen et al., 2012). BTD is an important proxy which allows detecting the managerial manipulation of accounting income and taxable income. A weak governance structure may increase the opportunistic behavior and earnings management practices. Managers would like to manage the earnings if its discretion is not controlled and delimited. The corporate governance has been the subject of several studies in the context of contractual theories. This concept is developed since Berle and Means (1932) who argue that managerial effectiveness depends primarily on the company's ownership structure. In fact, agency theory provides that the separation of ownership and control leads to a divergence in interest between the manager and the owner (Jensen \& Meckling 1976). Furthermore, the history of crises and scandals known in the world allows concluding that investors still have an anomaly in their expectations because of bad valuation of firms and insufficient information about the company's situation. These deficiencies have questioned the issue of corporate governance.

According to previous studies, this paper's main objective is to examine the relation between corporate governance and earnings manipulations using BTD proxy. Prior studies provide evidence that firm managers run their earnings to avoid the announcement of bad information such as weak performance and loss of income (Pourciau, 1993; Geiger \& North, 2011; Lasalle et al., 1993; Shabou \& Boulila 2002; Jeanjean, 2001; Gupta, 1995; Bowen et al., 2008) or to smooth earnings (Stolowy \& Breton, 2003; Nejad et al., 2013, Cheng \& Li, 2014). Some studies attribute earnings manipulations to fiscal purposes (Aboub \& Ben Amar, 2008; Breton \& Schatt, 2003). Regardless of earnings management objectives, the corporate governance implementation aims to monitoring and restricting corporate managers' discretion. A large body of research has examined the influence of corporate governance on information transparency. Information quality is altered by earnings and tax management.

Prior studies found a significant association between corporate governance and earnings management (Beasley, 1996; Dechow et al., 1996; McMullen, 1996) and tax management (Hanlon et al., 2005; Armstrong et al., 2014; Desai \& Dharmapala, 2006). Studies on the relationship between corporate governance and fiscal management are relatively a new line of research. In United States, Minnick and Noga (2010) was the first to examine this relationship. McMullen (1996) found that some governance mechanisms can reduce the publication of bad financial information. We continue these researches and contribute further to the debate by identifying the 
influence of governance mechanisms on the quality and content of financial statements in Tunisia setting measured by BTD. We examine whether the opportunistic source of BTD can be influenced by some governance mechanisms that are known in the literature by their effectiveness. We focus on listed companies where discretion is likely to be present. The specific characteristic of Tunisian company is that the institutional environment and the agency conflict differ from those in Anglo-Saxon countries. Tunisia is characterized by a large number of family firms, ownership concentration, the dominance of financial institutions, the authority of the state and less developed financial market (Dridi \& Boubaker, 2015; Ben Amar \& Abaoub, 2010).

This work tests a set of related hypotheses concerning the impacts of governance mechanisms on BTD which is an aggregate of earnings management and tax shelters. In doing so, the study provides a methodological framework in which we examine 21 firms over a period from the years 2003 to 2012. To test the hypotheses, the study uses regression analysis to investigate the relation between ownership structure, board of directors, audit committee and BTD. The results show that these mechanisms have an impact on accounting and tax management in Tunisian firms.

The remaining part of this article is organized as follows. Section 2 establishes the links between corporate governance and BTD. The research design is described in section 3. Section 4 reports the empirical results, followed by our conclusions in section 5 .

\section{Institutional Setting and Development of Hypotheses}

\subsection{Ownership Structure}

Ownership structure is an internal control mechanism for the company. An adequate structure can effectively influence the control of manager and monitoring cost. Most research recognized three elements that determine the ownership structure; the capital concentration, institutional investors and managerial ownership.

\subsubsection{Capital Concentration}

The capital concentration provides to shareholders an effective way to control manager because it minimizes the monitoring cost in the case of diluted capital. In fact, the volume of participation of large shareholders enhances them to control and impact the firm's strategy in firm which they have invested (Gonzalez \& Garcia-Meca, 2013). They indicate that opportunistic behavior is less present when the firm has ownership concentration. They conclude that high level of capital concentration in Latin America affects negatively the quality and transparency of financial information. They mentioned that ownership concentration can be an effective governance mechanism against managerial manipulation. Boubraki et al. (2005) report that capital concentration has a positive influence on information quality because the increase in the participation of the controlling shareholder allows to less incentives to wealth expropriation by manager. Beneish (1997) managerial manipulations are likely to be developed in firms with diluted capital. Alexander and Paquerot (2011) report that controlling shareholder has more incentives to invest in the monitor because the gain which it is associated is most important.

The capital concentration has not only one direction (a mechanism of control and alignment in interests). It can generate two contradictory effects. The first effect is to discipline the manager (in this case the capital concentration has an effective role especially for minority shareholders). The second effect is reversed; the interests of majority shareholders may lead them to appropriate the wealth of the company at the expense of minority shareholders. It is the case of entrenchment of the controlling shareholder (Shleifer \& Vishny, 1997; Firth et al., 2007; Gabrielsen et al., 2002; Fan \& Wong, 2002). In fact, a new type of agency problem appears between two categories that are controlling shareholders and minority shareholders. Fan and Wong (2002) corroborate this finding for the case of the East Asian companies, the high concentration of capital results in a low quality of informational result. Similarly, Firth et al (2007) find that firms with a high capital concentration have a low level of information power due to the effect of entrenchment. In the case of Kenyan companies, Waweru and Rio (2013) find that the capital concentration leads to a likely greater earnings management. Therefore, we propose and test the following hypothesis:

Hypothesis 1: The capital concentration negatively affects BTD.

\subsubsection{Institutional Ownership}

Institutional investors have an important role in corporate financing. In Tunisia, the financial sector (banks and leasing) in 2013 represents more than $45 \%$ of the total market capitalization. These investors constitute a controlling power. Indeed, these shareholders have privileged access to information that allows them a better understanding of the situation of the company and its sector and, therefore, a better appreciation of the diligence of the leaders. 
Yang et al. (2009) examined the ability of institutional investors against the activities of the earnings management. Based on a sample of 613 Malaysian companies between 2001 and 2003, these authors did not find evidence between the degree of earnings management and the proportion of institutional investors. These authors explain this result by the existence of the dominant managerial shareholders that can make difficult the intervention of institutional shareholders against earnings management. Wan and Wan (2009) have produced the same result in the case of family businesses. In the same lines, Choi and Seo (2008) have tried to detect the influence of institutional investors on accounting transparency within the companies listed in Korean stock exchanges for 1991 to 2003. Their results indicate that, if the level of institutional ownership increases, the opportunistic behavior of managers (relating to investments, financing activities and operating activities and others) is reduced. Indeed, they showe that firms that have a high level of managerial ownership have a higher accounting transparency. Koh (2003) and Hsu and Koh (2005) revealed that the influence of institutional investors can only take place after a certain share ownership threshold (about 50\%). This level allows them to act as a governance mechanism that can affect the outcome of management. Specifically, a low participation of institutional investors in the company's capital is considered an investment in the short term, while the high participation is considered as an economic investment so that investors are more concerned about the company's management and by managerial activities. Rajgopal et al. (1999) and Chung et al. (2002) found a negative relationship between discretionary accruals (proxy of the earnings management) and institutional investors. Njah and Jarboui (2013) examined the relationship between institutional ownership earnings management to the particular case of French absorbed companies. They found that the presence of institutional investors allows facing the managerial discretion of accruals. We address this view by testing the following hypothesis:

Hypothesis 2: Institutional Ownership negatively affects BTD.

\subsubsection{The Managerial Ownership}

The agency theory suggests that when managers are not owners of the entity which they manage or when they have low equity participation, their behavior is influenced by their own interests that are far from the objective of the company's value maximization. This indifference to the agent in the interest of the principal leads and facilitates the earnings management. The holding of shares by the company executive can reduce the conflict of interest and solve the agency problem. Moreover, the political and contractual theory argues that managers, holding a minimum of shares, are encouraged to manage earnings to increase more than the managers who hold a higher number of shares.

Warfield et al. (1995) find that in the case of the United States, the relationship between stock returns and accounting earnings is higher for companies that have high managerial ownership. Similarly, these authors found that the incentive to earnings management, motivated by managerial opportunism is reduced when the managerial ownership is high. However, Gabrielsen et al. (2002) and Yeo et al. (2002) show that the influence of managerial ownership as a governance mechanism differs across jurisdictions countries. He states that over the managerial ownership is greater the manager becomes more entrenched and the information becomes weaker. Similarly, Yeo et al. (2002) examine the nonlinear relationship between the managerial ownership and the income-increasing discretionary accruals. They find that, at low levels of managerial ownership, the level of incomes (increased by discretionary accruals) has a negative relationship with the managerial ownership. However, at higher levels of managerial ownership, the relationship is reversed. This result is explained by the effect of entrenchment. Similarly, Khan and Mather (2013) study the relationship between Value of managerial share ownership and discretionary accruals in Australian companies. They find a non-monotonic and convex relationship between the two of them. Moreover, Abed et al. (2012) find a significant and negative relationship between ownership of insiders and earnings management. This result is explained by the fact that this relationship varies depending on the level of the value of the managerial ownership.

Hypothesis 3: The managerial ownership negatively affects BTD.

\subsection{Board of Directors}

The Board of Directors presents the delegated organization of shareholders which allows the supervision missions, executive compensation and replacement. This organization is able to approve strategic investments and overseeing all business activities. Its importance in the entity has led many researchers to study its effectiveness in the fight against earnings management and tax management (Peasnell et al., 2005; Minnick \& Noga, 2010; Firth et al., 2007, Wan \& Wan, 2009; Armstrong et al., 2014, Zemzem \& Ftouhi; 2013). Previous studies showed that the effectiveness of the board depends on some features including; board size, its independence, and the duality of the manager. However, the appropriate composition of the Board and its impact on performance are divergent (Minnick \& Noga, 2010). 


\subsubsection{Board Size}

The board size is an important element of the features of the board which allows coping with aggressive managerial manipulation. The Tunisian code of good governance practices recommended size from seven to nine directors. This number presents the best size that promotes quick decision making and expanded. Likewise, the literature argues that large boards are generally perceived as being less effective in the exchange of ideas and promote the coalition between board members (Firth et al., 2007). In this sense, Gonzalez and Garcia-Meca (2013) indicated that the excessive size can be an obstacle to speed and efficiency in decision making because of coordination and communication problems. Moreover, Jensen (1993) suggested that large boards are less efficient than small ones. Similarly, Beasley (1996) found that the likelihood of accounting fraud increases with the size of the board. Zemzem and Ftouhi (2013) revealed for the case of French companies that a small board decreases tax aggressiveness. Yermack (1996) also showed that a small size of the board is more effective than large board size. Lanis and Richardson (2011) found a significant relationship between the number of board members and tax aggressiveness. In the context of Greek companies Dimitropoulos and Asteriou (2010) have not found a relationship between the size of the Board and the informational power of the accounting result. However Xie et al. (2003) and Ghosh et al. (2010) and Abed et al. (2012) show a negative relationship. Thus, it arises the following hypothesis.

Hypothesis 4: the board size is positively related to BTD

\subsubsection{Board Independence}

The Board has a number of internal as well as external directors. These provide effective control of managers according to agency theory. Indeed, external members can ensure the competence and independence at the same time. However, internal directors are frustrated by some dependence as their hierarchical position relative to the management. This dependence prevents the ability of administrators against managerial decisions. Empirical studies in developed countries (Beasley, 1996; Peasnell et al., 2000; Armstrong et al., 2014, Richardson et al., 2013) have shown that companies with a very independent board are less exposed to violations accounting and tax matters. However, Minnick and Noga (2010) assumed that the independent directors may be willing to tax management to improve business performance. These administrators can provide useful knowledge from their own experiences and their industry. Gonzalez and Garcia-Meca (2013) assumed that board independence negatively affects earnings of management. Armstrong et al. (2014) found that the board independence has a positive relationship with tax avoidance in the upper tail of the distribution of tax evasion and a negative relationship in the lower tail. These authors affirm that their results are consistent with the hypothesis that sophisticated and independent board can detect decisions of the tax aggressiveness and potential agency problems.

Moreover, Richardson et al. (2013) examined the relationship between the board and tax aggressiveness in the case of Australian companies. Their results indicated that the effect of the interaction between the independence of directors, the establishment of an effective risk management system and internal control together reduced the tax aggressiveness. In the same context, Lanis and Richardson (2011) showed, through a logit regression for a sample of 32 companies, the inclusion of a high proportion of external members in the board reduces the likelihood of aggression tax. Based on a sample of Iranian companies during 2010-2012, Jalali et al. (2013) concluded that the external members significantly affect the strategies of tax aggressiveness. The results of Waweru and Riro (2013) suggested, too, that companies have a more independent board are less likely to manage their results. Xie et al. (2003) found that the result management is less likely to occur in companies with their boards include both independent directors and directors with experience in companies.

Yang et al. (2009) found no evidence between the degree of income management and the proportion of outside directors. These authors developed some possible explanations to the inefficiency of control of outside directors in the fight against income management in Malaysia. According to these authors, outside directors may lack the financial expertise required for earnings management detection. Thus, the efficiency of the supervisory Board depends on the ability of outside directors to understand the methods of the earnings management. This result is corroborated by Wan and Wan (2009), which showed no relationship between the proportion of outside directors and the best quality of the information disclosed. Zemzem and Ftouhi (2013) and Aliani and Zarai (2012) have not confirm their hypothesis of the impact of outside directors on the level of tax aggressiveness. This result is corroborated with Ghosh et al. (2010) and Abed et al. (2012) who have not found an association between board independence and some proxies of earnings management.

Hypothesis 5: The Board Independence negatively affects BTD. 


\subsubsection{CEO Duality}

Several studies have examined the cumulative effect of the function of chief executive and president of the board on managerial decision and information related to the company. Indeed, Fama and Jensen (1983) report that when ownership and control are concentrated in a small number of decision agents, it is rational for these agents to invest in less risky projects because these agents have given up the reduction of the optimal risk through portfolio diversification.

However, both roles by the leader may prevent governance target to deal with transparency, independence and control board. Gonzalez and Garcia-Meca (2013) report that CEO duality leads to a concentration of power in the company and assumed that it favors earnings management. The CEO duality facilitates and promotes management entrenchment and the agency conflict. However, Minnick and Noga (2010, p. 706) argue that companies which are the subject of entrenchment through the accumulation of functions, are likely to have a low level of tax management and a high tax burden. Jensen (1993, p. 866) observe that the manager cannot execute the mission without the chairman's personal interest. Thus, the effectiveness of the Board is the separation of these two functions.

Jalali et al. (2013) confirmed their hypothesis and found that the CEO duality significantly impact the tax aggressiveness. Similarly, Abed et al. (2012) found a significant positive relationship between earnings management and the duality of the manager. Zemzem and Ftouhi (2013) assumed that the function accumulated by the leader usefully affect the level of tax aggressiveness. However, these authors did not confirm their hypothesis. Similarly, Ghosh et al. (2010) and Firth et al. (2007) found that the CEO duality does not affect the outcome of management. Badertscher et al (2013) analyze the impact of organizational structure on corporate tax avoidance. Their results indicate that corporate tax avoidance increases in the case of the separation of ownership and control

Hypothesis 6: The concentration of power (CEO Duality) increases BTD.

\subsection{Audit Committee}

The Audit Committee is a body established within the Board of Directors, whose role is to improve the quality of financial reporting. While the board supports various responsibilities in the management of the company, it generally delegates specific functions to other committees, the most important the audit committee. As part of the Board of Directors, the Audit Committee supports in particular the function of supervising the company's financial reporting process. Thus, the efficiency, performance and quality of the audit committee are based on certain characteristics that its independence and expertise.

\subsubsection{Audit Committee Composition}

The composition of the audit committee can be a means of detecting its credibility and independence. An independent audit committee can protect members against the pressures that can come from management. Therefore, the effect of the independence of the audit committee was considered in most management studies (Ghosh et al., 2010 Xie et al., 2003; Robinson et al., 2012). A common presumption provides that a more independent committee allows more effective control and therefore a better quality of earnings released by the company. Richardson et al. (2013) report that the audit committee should be represented by a majority of independent members. The Audit Committee monitors the process of financial information and related functions of the company. The independent members of the Audit Committee are envisaged to enhance the reputation of the company's capital through more effective control of management (Fama \& Jenson, 1983). Klein (2002) examined whether the audit committee is linked to the earnings management. This author shows a negative relationship between the independence of the audit committee and abnormal accruals. Indeed, a reduction in the independence of the Audit Committee leads to an increase of abnormal accruals. Richardson et al. (2013) predicted that the independence of the audit committee plays an important role in reducing the possibility of tax aggressiveness. Moreover, these authors confirm the hypothesis of a negative association between the independence of the audit committee and fiscal aggressiveness of the firm. This result is confirmed by Bryan et al. (2004). Abbott et al. (2000) show that the companies which have audit committee composed of outside directors, are less likely to be punished for fraud in financial reporting. Similarly, Xie et al. (2003) found that the composition of the audit committee is associated with earnings management. Yang and Krishnan (2005) did not find an association between the independence of the audit committee and quarterly discretionary accruals. Beasley (1996) claimed that the boards of companies in situations of fraud are less likely to have an audit committee.

Hypothesis 7: The Audit Committee Independence affects negatively BTD. 


\subsubsection{Audit Committee Expertise}

Robinson et al. (2012) examined the association between tax avoidance and the financial expertise of the audit committee. These authors showed that the financial expertise of the committee is generally positively associated with tax planning. However, this association becomes negative when tax planning takes an aggressive appearance. Ghosh et al. (2010) analyze the impact of the financial expertise on discretionary accruals. These authors did not confirm the presence of a financial expert in the audit committee is associated with the earnings management. These results do not conform to those of Bedard et al. (2004) and Carcello et al. (2006) who found that the presence of at least a member in the committee with financial expertise is associated with a lower likelihood of aggression in earnings management. This result is confirmed by Abbott et al. (2000). The result of Yang and Krishnan (2005) show no significant association between the existence of a financial expert and quarterly discretionary accruals. Huang and Thiruvadi (2010) found that financial expertise is significantly associated with fraud prevention. These authors suggested that the presence of financial expert on the committee is more likely in client's international audit firms.

Hypothesis 8: Audit Committee Expertise affects negatively BTD.

\section{Research Design}

The database covers 10 years (2003-2012) and includes 21 companies, a total of 210 observations. This limitation is imposed by the data collection conditions. We developed a database with particular characteristics. We collected information from companies listed on the stock exchange in order to collect information on the ownership structure, the Board of Directors and the Audit Committee. The firms in our sample are limited companies since they are represented by a Board of Directors. The choice of the sample covers the different types of industries, industrial and commercial activities, transport companies, communication, real estate and other activities. The sample is made considering the sector-specific regime of some companies. Indeed, we eliminated companies that belong to the financial sector. These companies do not have the same governance mechanisms and their managers may not have the same behavior and the same objectives of earnings manipulation. This sample is cylindered, and all companies are present on the 10 years of the study. Financial data and data related to corporate governance variables are collected from the financial statement and the annual reports available on the website of the Financial Market Council.

\subsection{Variables of the Study}

- dependent variable: BTD

Following prior studies (Tang \& Firth, 2011; Tang \& Firth, 2012; Formigoni et al., 2009, Dridi \& Boubaker, 2015), we separate BTD into two components, normal and abnormal differences. The reason is that abnormal differences are more informative about managerial manipulations because it represents the part which is not explained by the differences between accounting and tax treatment. This approach allows taking the total difference and subtracting the different items that may increase the gap of BTD.

In fact, the component which measures ABTD is the residual regressed on variables related to the difference treatments between accounting and taxation (Eq.1). NBTD is a result of difference between accounting standards and tax laws. It is divergence in the treatment of goodwill $(\mathrm{GW})$, investment in gross property ( $\triangle \mathrm{PPE})$, economic growth $(\triangle \mathrm{REV})$, foreign operations $(\mathrm{FO})$ and stock portfolio $(\triangle \mathrm{SP})$.

$$
B T D_{i, t}=\alpha_{0}+\alpha_{1} G W_{i, t}+\alpha_{2} \Delta P P E_{i, t}+\alpha_{3} \Delta R E V_{i, t}+\alpha_{4} F O_{i, t}+\alpha_{5} \Delta S P_{i, t}+\varepsilon_{i}
$$

Where; $\mathrm{BTD}_{\mathrm{i}, \mathrm{t}}$ : book-tax differences of firm i in year t, this variable is equal to income before tax minus taxable income scaled by total assets; $\mathrm{GW}_{\mathrm{i}, \mathrm{t}}$ : goodwill of firm $\mathrm{i}$ in year $\mathrm{t}$, this variable is equal to the gross value of goodwill scaled by total assets; $\Delta \mathrm{INV}_{\mathrm{i}, t}$ : change in investment in gross property, plants and equipment from year $\mathrm{t}-1$ to year $\mathrm{t}$, this variable is equal to the gross value of tangible assets in year $\mathrm{t}$ minus the gross value of tangible assets in year $\mathrm{t}-1 ; \Delta \mathrm{REV}_{\mathrm{i}, \mathrm{t}}$ changes in revenues, this variable is equal to the revenue in year $\mathrm{t}$ minus the revenue in year $\mathrm{t}-1 ; \mathrm{FO}_{\mathrm{i}, \mathrm{t}}$ : the foreign operations of firm $\mathrm{i}$ in year $\mathrm{t}$, this variable is measured by a binary value which takes 1 if the firm has make foreign operations in year $\mathrm{t}$ in 0 otherwise; $\Delta \mathrm{SP}_{\mathrm{i}, \mathrm{t}}$ : change in stock portfolio from year $t-1$ to year $t$, this variable is equal to the value of stock portfolio in year $t$ minus the value of stock portfolio in year $\mathrm{t}-1$ scaled by total assets.

- Explanatory and control variables measurement 
Table 1. Explanatory and control variables definition

\begin{tabular}{|c|c|c|c|}
\hline Variable & Code & Measurement & Authors \\
\hline \multicolumn{4}{|c|}{ Panel A: Explanatory variables measurement } \\
\hline $\begin{array}{l}\text { Capital } \\
\text { Concentration }\end{array}$ & CAP-Con & $\begin{array}{l}\text { A dichotomous variable equals to } 1 \text { if the proportion of } \\
\text { shares held by the largest shareholder exceeds } 50 \% \text { and } \\
0 \text { otherwise }\end{array}$ & Shabou (2000) \\
\hline $\begin{array}{l}\text { Institutional } \\
\text { Ownership }\end{array}$ & Inst_OWN & $\begin{array}{l}\text { measured by the proportion of shares held by } \\
\text { institutional investors }\end{array}$ & $\begin{array}{l}\text { Gonzalez et Garcia-Meca (2013) } \\
\text { Rajgopal et al (1999) Xie et al (2003) }\end{array}$ \\
\hline $\begin{array}{l}\text { The Managerial } \\
\text { Ownership. }\end{array}$ & Man_OWN & $\begin{array}{l}\text { measured by the proportion of shares owned by } \\
\text { managers }\end{array}$ & $\begin{array}{l}\text { Abbott et al (2000) Ghosh et al } \\
(2010)\end{array}$ \\
\hline Board Size & Board_SIZE & Total number of board members & $\begin{array}{l}\text { Gonzalez et Garcia-Meca (2013) } \\
\text { Ghosh et al (2010) Beasley (1996) } \\
\text { Yermack (1996) }\end{array}$ \\
\hline $\begin{array}{l}\text { Proportion } \\
\text { Independent } \\
\text { Directors }\end{array}$ & Bord_IND & $\begin{array}{l}\text { Number of independent non-executive directors to total } \\
\text { number of board members }\end{array}$ & $\begin{array}{l}\text { Gonzalez et Garcia-Meca (2013) } \\
\text { Ghosh et al (2010) Armstrong et al } \\
\text { (2014) }\end{array}$ \\
\hline CEO Duality & DUA & $\begin{array}{l}\text { A dichotomous variable equals to } 0 \text { if the firm } i \text { is } \\
\text { separated between the role of } C E O \text { and Chairman, } \\
\text { and } 1 \text { otherwise. }\end{array}$ & $\begin{array}{l}\text { Gonzalez et Garcia-Meca (2013) } \\
\text { Ghosh et al (2010) Firth et al (2007) }\end{array}$ \\
\hline $\begin{array}{l}\text { Audit Committee } \\
\text { Composition }\end{array}$ & Audit_IND & $\begin{array}{l}\text { The number of directors on } \\
\text { the audit committee }\end{array}$ & $\begin{array}{l}\text { Yang et Krishnan (2005) Ghosh et al } \\
\text { (2010) Xie et al (2003) }\end{array}$ \\
\hline $\begin{array}{l}\text { Audit Committee } \\
\text { Expertise }\end{array}$ & Audi_EXP & $\begin{array}{l}\text { A dichotomous variable that equals one when the audit } \\
\text { committee has at least one director with financial } \\
\text { expertise and } 0 \text { otherwise. }\end{array}$ & Ghosh et al (2010) \\
\hline \multicolumn{4}{|c|}{ Panel B: Control variables measurement } \\
\hline Financial leverage & LEV & Total debt to total assets. & Abed et al (2012) Ghosh et al (2010) \\
\hline Firm size & Firm_SIZE & $\begin{array}{l}\text { The natural logarithm of total assets at the fiscal } \\
\text { year-end; }\end{array}$ & Ghosh et al (2010) \\
\hline $\begin{array}{l}\text { External audit } \\
\text { quality. }\end{array}$ & BIG4 & $\begin{array}{l}\text { A dichotomous variable that equals one when the firm is } \\
\text { audited by a large auditor and } 0 \text { otherwise }\end{array}$ & Ghosh et al (2010) \\
\hline $\begin{array}{l}\text { Financial Security } \\
\text { Act }(2005)\end{array}$ & SOX & $\begin{array}{l}\text { A dichotomous variable that equals to } 1 \text { if the year is } \\
\text { after } 2005,0 \text { otherwise }\end{array}$ & Ghosh et al (2010) \\
\hline
\end{tabular}

Author (Own elaboration).

\subsection{Regression Model Specifications}

To verify our research hypotheses we apply a statistical methodology implementing a linear panel regression. From this regression we are going to test the effect of the variables of the corporate governance as well as the control variables on the ABTD variable. Our mode is as follows:

$$
\begin{gathered}
A B T D_{i, t}=\alpha_{0}+\alpha_{1} \text { CAP-Con }_{i, t}+\alpha_{2} \text { Inst_OWN }_{i, t}+\alpha_{3} \text { Man_OWN }_{i, t}+\alpha_{4} \text { Board_SIZE }_{i, t}+\alpha_{5} \text { Bord_IND }_{i, t}+\alpha_{6} \\
\text { DUA }_{i, t}+\alpha_{7} \text { Audit_IND } \\
i, t
\end{gathered}
$$

Where; ABTD: abnormal book-tax differences; CAP-Con: Capital Concentration, measured by a dichotomous variable equal to lif the proportion of shares held by the largest shareholder exceeds $50 \%$ and 0 otherwise; Inst_OWN: Institutional Ownership, measured by the proportion of shares held by institutional investors; Man_OWN: The Managerial Ownership, measured by the proportion of shares owned by managers; Board_SIZE: Size of board's directors, measured by the total number of board members; Bord_IND: Proportion of Independent Directors, measured by the number of independent non-executive directors to total number of board members; DUA: CEO Duality, measured by a dichotomous variable equal to 0 if the firm i is separated between the role of CEO and Chairman, and 1 otherwise; Audit_IND: Audit Committee Composition, measured by the number of directors on the audit committee; Audi_EXP: Audit Committee Expertise, measured by a dichotomous variable that equals one when the audit committee has at least one director with financial expertise and 0 otherwise; LEV: Financial leverage, measured by the total debt to total assets.; Firm_SIZE: Firm size, measured by the natural logarithm of total assets at the fiscal year-end; BIG4: External audit quality, measured by a dichotomous variable that equals one when the firm is audited by a large auditor and 0 otherwise; SOX: Financial Security Act, measured by a dichotomous variable that equals to 1 if the year is after 2005, 0 otherwise 


\section{Results}

\subsection{Descriptive and Univariate Statistics}

Table 2. Descriptive statistics and mean comparison of dichotomous variables

\begin{tabular}{|c|c|c|c|c|c|}
\hline Variable & Modalities & Frequency & Mean ABTD & Student test & Fisher test \\
\hline \multirow[t]{2}{*}{ CAP-Con } & 0 & 0.718 & -0.0059 & $(0.707)$ & $(0.689)$ \\
\hline & 1 & 0.282 & -0.0123 & & \\
\hline \multirow[t]{2}{*}{ DUA } & 0 & 0.121 & -0.0178 & $(0.593)$ & $(0.495)$ \\
\hline & 1 & 0.879 & -0.0052 & & \\
\hline \multirow[t]{2}{*}{ Audi_EXP } & 0 & 0.834 & -0.0145 & $(0.067) *$ & $(0.003)^{* *}$ \\
\hline & 1 & 0.166 & 0.0235 & & \\
\hline \multirow[t]{2}{*}{ BIG4 } & 0 & 0.737 & -0.0117 & $(0.392)$ & $(0.083)^{*}$ \\
\hline & 1 & 0.263 & 0.0031 & & \\
\hline
\end{tabular}

CAP-Con: Capital Concentration; DUA: CEO Duality; Audi_EXP: Audit Committee Expertise; BIG4: External audit quality. $* / * * / * * *$ represent significance at the $10 / 5 / 1 \%$ level, respectively.

Author (Own elaboration).

Table 2 shows the descriptive statistics and means comparison of qualitative variables. The results show that $28 \%$ of Tunisian listed companies have a shareholder with more than half of the shares. Despite the capital structure reflecting a small percentage of ownership concentration, $87 \%$ of these companies are managed by an executive who is chairman the board of directors. The existence of an expert in the audit committee affects almost $20 \%$ of companies. This result reflects the neglect of this as governance mechanism in Tunisian companies. This table shows that only $26 \%$ of Tunisian companies are audited by an international auditor.

Under the bivariate analysis, the relationship between the dependent variable in our model and the independent variables (which are qualitative) is measured by an average analysis. We detected the significance of relationships through two tests. The first test of equal average is conducted through the Student test. This test assumes a normality distribution of the variable. To overcome the problem of non-normality, we used the nonparametric Kruskal and Wallis test. The results show that both tests show the same result of significance except for the BIG4 variable. The test is significant only for the Audi_EXP variable.

Table 3. Descriptive statistics and correlations

\begin{tabular}{|c|c|c|c|c|c|c|c|c|}
\hline \multicolumn{9}{|c|}{ Panel A: Descriptives statistics } \\
\hline Variable & $N$ & & Mean & \multicolumn{2}{|c|}{ Std. Dev. } & \multicolumn{2}{|l|}{ Min } & $\operatorname{Max}$ \\
\hline$A B T D$ & 210 & & -0.008 & \multicolumn{2}{|l|}{0.110} & \multicolumn{2}{|l|}{-0.497} & 0.971 \\
\hline Inst_OWN & 210 & & 0.099 & \multicolumn{2}{|l|}{0.175} & \multicolumn{2}{|l|}{0} & 0.607 \\
\hline Man_OWN & 210 & & 0.062 & \multicolumn{2}{|l|}{0.176} & \multicolumn{2}{|l|}{0} & 0.685 \\
\hline Board_SIZE & 210 & & 9.485 & \multicolumn{2}{|l|}{2.181} & \multicolumn{2}{|l|}{4} & 12 \\
\hline Bord_IND & 210 & & 0.814 & \multicolumn{2}{|l|}{0.168} & \multicolumn{2}{|l|}{0.375} & 0.916 \\
\hline Audit_IND & 210 & & 0.888 & \multicolumn{2}{|l|}{0.200} & \multicolumn{2}{|l|}{0.333} & 1 \\
\hline$L E V$ & 210 & & 0.392 & \multicolumn{2}{|l|}{1.546} & \multicolumn{2}{|l|}{0.005} & 0.005 \\
\hline Firm_SIZE & 210 & & 17.955 & \multicolumn{2}{|l|}{1.073} & 13.319 & & 21.131 \\
\hline \multicolumn{9}{|c|}{ Panel B: Pearson correlation coefficients. } \\
\hline & $A B T D$ & Inst_OWN & Man_OWN & Board_SIZE & Bord_IND & Audit_IND & $L E V$ & Firm_SIZE \\
\hline$A B T D$ & 1.000 & & & & & & & \\
\hline Inst_OWN & $-0.246 * * *$ & 1.000 & & & & & & \\
\hline Man_OWN & 0.026 & $-0.200 * * *$ & 1.000 & & & & & \\
\hline Board_SIZE & -0.069 & $0.150 * *$ & $-0.415 * * *$ & 1.000 & & & & \\
\hline Bord_IND & $-0.128^{*}$ & -0.032 & $-0.035 * * *$ & $0.348 * * *$ & 1.000 & & & \\
\hline Audit_IND & 0.0169 & -0.039 & $0.128^{*}$ & 0.059 & 0.088 & 1.000 & & \\
\hline$L E V$ & -0.076 & -0.070 & $0.119^{*}$ & 0.032 & 0.011 & -0.010 & 1.000 & \\
\hline Firm_SIZE & -0.080 & 0.006 & -0.194 & $0.374 * *$ & $0.184 * * *$ & 0.103 & $-0.449 * * *$ & 1.000 \\
\hline
\end{tabular}

Where; ABTD: abnormal book-tax differences; Inst_OWN: Institutional Ownership, measured by the proportion of shares held by institutional investors; Man_OWN: The Managerial Ownership, measured by the proportion of shares owned by managers; Board_SIZE: Size of board's directors, measured by the total number of board members; Bord_IND: Proportion of Independent Directors, measured by the 
number of independent non-executive directors to total number of board members; Audit_IND: Audit Committee Composition, measured by the number of directors on the audit committee; LEV: Financial leverage, measured by the total debt to total assets.; Firm_SIZE: Firm size, measured by the natural logarithm of total assets at the fiscal year-end.

$* / * * / * * *$ represent significance at the $10 / 5 / 1 \%$ level, respectively.

Author (Own elaboration).

Table 3 presents the descriptive statistics and correlation of the quantitative variables. Panel A shows that on average firms recorded ABTD for $0.8 \%$ of total assets. It shows that institutional investors hold on average a very small percentage of $9 \%$ in the capital of listed companies of which $60 \%$ is the maximum detention. The result on the percentage holding of shares by the manager is not as far from preceding results. The average of the managerial ownership is 6\% while a maximum level of ownership is 68\%. Descriptive statistics show that board size ranges from 4 to 12 directors with an average of 9 . On average $83 \%$ of the directors are external, this result is similar to that of Aliani and Zarai (2012) which showed that the percentage independent directors in the board is on average $81 \%$ in Tunisian companies. This panel shows that on average $88 \%$ of members of the Audit Committee are independent. The permanent audit committee may be composed entirely of outside directors.

We review in panel B the correlation of quantitative variables to ensure the absence of a strong correlation which may bias our results. The test is performed using the correlation Person. Preliminary analysis of this table shows the absence of a strong correlation between variables that can bias our estimates and consequently an absence of multicollinearity. This Panel shows that BTD has a significantly positive association with Inst_OWN and Bord_IND, consistent with our predictions

\subsection{Multivariate Analysis}

\subsubsection{Testing Panel Data}

Table 4. Model specification tests

\begin{tabular}{|c|c|c|c|}
\hline & Tests & Hypotheses. & Results \\
\hline \multicolumn{4}{|l|}{ Panel A: model specification } \\
\hline \multirow[t]{4}{*}{ specification test } & Fisher test & HO : no fixed effects & $F(20,172)=6.08$ \\
\hline & & & Prob $>\mathbf{F}=\mathbf{0 . 0 0 0}$ \\
\hline & Hausman test & $\mathrm{H} 0$ : presence of random effects. & Chi2 $(11)=81.99$ \\
\hline & & & Prob $>$ chi $2=0.000$ \\
\hline \multicolumn{4}{|l|}{ Panel B: testing panel data } \\
\hline \multirow{3}{*}{$\begin{array}{l}\text { Residuals normality test. } \\
\text { Ramsey Reset test. }\end{array}$} & Shapiro-Wilk & $\mathrm{H} 0$ : the errors are normally distributed & Prob $>z=0.000$ \\
\hline & Ramsey Reset. & H0: well specified model & $\mathrm{F}(3,198)=8.39$ \\
\hline & & & Prob $>F=0.000$ \\
\hline \multirow[t]{2}{*}{ Heteroscedasticity test } & Breush and Pagan & $\mathrm{H} 0$ : the variance is homoscedastic. & Chi2 $(01)=60.91$ \\
\hline & & & Prob $>$ chi $2=0.000$ \\
\hline \multirow{2}{*}{$\begin{array}{l}\text { Autocorrelation } \\
\text { test. }\end{array}$} & Wooldridge & $\mathrm{H} 0$ : the residuals are not autocorrelated & $F(1,20)=1.108$ \\
\hline & & . & Prob $>F=0.305$ \\
\hline
\end{tabular}

Author (Own elaboration).

The analysis of the econometric model has to pass first through some tests that ensure the model specification. We used the Fisher test to discriminate the presence or absence of specific effects in panel data. The probability associated with the test is less than $1 \%$ which shows specific effects to each company in our model. The Hausman test aims to control whether or not a correlation between the specific effects and the explanatory variables of the model. This table shows that the choice of the fixed effects model is more appropriate because the probability is less than $1 \%$. The result of residual normality test (Shapiro-Wilk), gives us a p-value equal to 0.000 . This p-value is strictly less than the threshold $\alpha=5 \%$, which means that the test is significant. The normality of residuals is not verified in our model. Regarding the Ramsey RESET test, p-value is strictly less than the threshold $\alpha=5 \%$. The test is significant. The model is not well specified. The homoscedasticity test for the case of fixed-effects model is done through the Breusch -Pagan test. We conclude the heteroscedasticity of the model. The auto correlation error test is conducted through the Wooldridge test (2002). We can conclude that the residual is auto-correlated. We correct this problem through the Generalized Least Squares method. 


\subsubsection{Regression Results}

Table 5. Estimated coefficients from the model

\begin{tabular}{|c|c|c|c|}
\hline \multicolumn{4}{|c|}{ 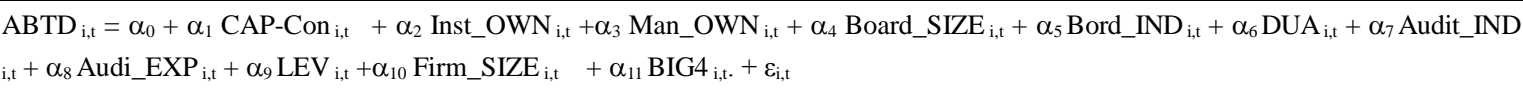 } \\
\hline Variables & Predicted sign & Coefficient & Probability \\
\hline Intercept $\left(\alpha_{0}\right)$ & - & 0.281 & 0.030 \\
\hline CAP-Con $\left(\alpha_{1}\right)$ & - & -0.028 & 0.048 \\
\hline Inst_OWN $\left(\alpha_{2}\right)$ & - & -0.135 & 0.001 \\
\hline Man_OWN $\left(\alpha_{3}\right)$ & - & 0.006 & 0.885 \\
\hline Board_SIZE $\left(\alpha_{4}\right)$ & + & 0.004 & 0.147 \\
\hline Bord_IND $\left(\alpha_{5}\right)$ & - & -0.139 & 0.004 \\
\hline $\operatorname{DUA}\left(\alpha_{6}\right)$ & + & 0.000 & 0.973 \\
\hline Audit_IND $\left(\alpha_{7}\right)$ & - & -0.014 & 0.125 \\
\hline Audi_EXP $\left(\alpha_{8}\right)$ & - & 0.031 & 0.008 \\
\hline $\operatorname{LEV}\left(\alpha_{9}\right)$ & & 0.033 & 0.029 \\
\hline Firm_SIZE $\left(\alpha_{10}\right)$ & & -0.010 & 0.143 \\
\hline $\operatorname{BIG} 4\left(\alpha_{11}\right)$ & & -0.041 & 0.005 \\
\hline Chi2 & & 60.91 & $(\mathrm{P}=0.000)$ \\
\hline $\mathbf{N}$ & & 210 & 210 \\
\hline
\end{tabular}

Where; ABTD: abnormal book-tax differences; CAP-Con: Capital Concentration, measured by a dichotomous variable equal to 1 if the proportion of shares held by the largest shareholder exceeds 50\% and 0 otherwise; Inst_OWN: Institutional Ownership, measured by the proportion of shares held by institutional investors; Man_OWN: The Managerial Ownership, measured by the proportion of shares owned by managers; Board_SIZE: Size of board's directors, measured by the total number of board members; Bord_IND: Proportion of Independent Directors, measured by the number of independent non-executive directors to total number of board members; DUA: CEO Duality, measured by a dichotomous variable equal to 0 if the firm i is separated between the role of CEO and Chairman, and 1 otherwise; Audit_IND: Audit Committee Composition, measured by the number of directors on the audit committee; Audi_EXP: Audit Committee Expertise, measured by a dichotomous variable that equals one when the audit committee has at least one director with financial expertise and 0 otherwise; LEV: Financial leverage, measured by the total debt to total assets.; Firm_SIZE: Firm size, measured by the natural logarithm of total assets at the fiscal year-end; BIG4: External audit quality, measured by a dichotomous variable that equals one when the firm is audited by a large auditor and 0 otherwise.

Author (Own elaboration).

The Table 5 shows that most of the independent variables are individually significant in explaining the dependent variable. The variables (CAP-Con, Inst_OWN, Bord_IND, Audi_EXP, LEV and BIG4) have significant values through a lower p-value at the $5 \%$ threshold.

CAP-Con has a significant value to explain the ABTD. The negative sign of the coefficient of this variable indicates that the concentration of ownership negatively affects the level of ABTD. This result is confirmed by Beneish (1997) how shows that companies that have diluted capital are likely to present an opportunistic behavior. We conclude from this result that the ownership concentration is an effective governance mechanism for the fight against managerial discretions. This result leads to validate the $\mathrm{H} 1$ hypothesis. Moreover, this result is consistent with that of Gonzalez and Garcia-Meca (2013), Alexander and Paquerot, (2011) and Alves (2012).

The regression variables confirm significance between ABTD and Inst_OWN. In fact, the result shows a strictly lower p-value threshold $\alpha=5 \%$. This result allows confirming the H2 hypothesis; institutional ownership negatively affects BTD. Institutional investors present a governance mechanism that affects the level of managerial manipulations. The coefficient on Man_OWN and Board_SIZE are not significant, suggesting that the percentage of managerial ownership and the size of board's directors do not affect the ABTD. The results show that estimate coefficient on the variable Bord_IND is negative and significant ( $\mathrm{p}-\mathrm{v}=0.00)$. This finding is consistent with our predictions. The negative sign for this variable results in the fact that the introduction of a higher proportion of external members in the company reduces the level of managerial manipulation. The H5 hypothesis is valid. The coefficient on DUA and Audit_IND are not significant; suggesting that these variables cannot affects manager manipulations. The coefficients on Audi_EXP which measure the audit committee expertise is negative and significant. The presence of at least one member in the audit committee with financial 
expertise reduced managerial discretions. The results show that estimates coefficients on the variables LEV and BIG4 are significant.

Table 6. Estimated coefficients after interaction

\begin{tabular}{|c|c|c|c|c|c|}
\hline \multicolumn{6}{|c|}{ 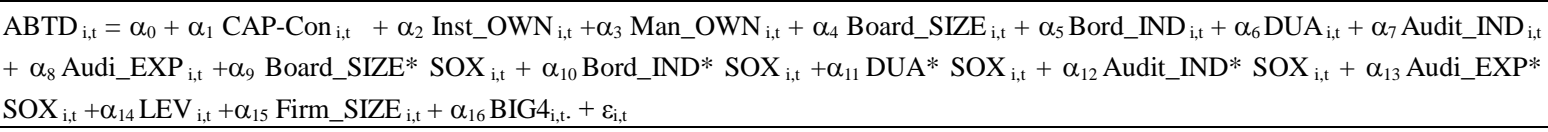 } \\
\hline Variables & Predicted sign & Coefficient & Probability & Coefficient & Probability \\
\hline Intercept $\left(\alpha_{0}\right)$ & - & 0.281 & 0.030 & 0.278 & 0.047 \\
\hline CAP-Con $\left(\alpha_{1}\right)$ & - & -0.028 & 0.048 & -0.031 & 0.024 \\
\hline Inst_OWN $\left(\alpha_{2}\right)$ & - & -0.135 & 0.001 & -0.143 & 0.001 \\
\hline Man_OWN $\left(\alpha_{3}\right)$ & - & 0.006 & 0.885 & 0.010 & 0.814 \\
\hline Board_SIZE $\left(\alpha_{4}\right)$ & + & 0.004 & 0.147 & 0.003 & 0.583 \\
\hline Bord_IND $\left(\alpha_{5}\right)$ & - & -0.139 & 0.004 & -0.125 & 0.094 \\
\hline $\operatorname{DUA}\left(\alpha_{6}\right)$ & + & 0.000 & 0.973 & -0.001 & 0.961 \\
\hline Audit_IND $\left(\alpha_{7}\right)$ & - & -0.014 & 0.125 & -0.123 & 0.000 \\
\hline Audi_EXP $\left(\alpha_{8}\right)$ & - & 0.031 & 0.008 & 0.040 & 0.140 \\
\hline $\operatorname{SOX}\left(\alpha_{9}\right)$ & & & & -0.001 & 0.978 \\
\hline Board_SIZE* SOX $\left(\alpha_{10}\right)$ & & & & 0.000 & 0.934 \\
\hline Bord_IND* $\operatorname{SOX}\left(\alpha_{11}\right)$ & & & & -0.002 & 0.973 \\
\hline DUA* $\operatorname{SOX}\left(\alpha_{12}\right)$ & & & & 0.004 & 0.909 \\
\hline Audit_IND* $\operatorname{SOX}\left(\alpha_{13}\right)$ & & & & 0.109 & 0.001 \\
\hline Audi_EXP* $\operatorname{SOX}\left(\alpha_{14}\right)$ & & & & -0.001 & 0.694 \\
\hline $\operatorname{LEV}\left(\alpha_{15}\right)$ & & 0.033 & 0.029 & 0.040 & 0.005 \\
\hline Firm_SIZE $\left(\alpha_{16}\right)$ & & -0.010 & 0.143 & -0.010 & 0.173 \\
\hline $\operatorname{BIG} 4\left(\alpha_{17}\right)$ & & -0.041 & 0.005 & -0.040 & 0.007 \\
\hline Chi2 & & 60.91 & $(\mathrm{P}=0.000)$ & 78.46 & $(\mathrm{P}=0.000)$ \\
\hline $\mathbf{N}$ & & 210 & & 210 & \\
\hline
\end{tabular}

Where; ABTD: abnormal book-tax differences; CAP-Con: Capital Concentration, measured by a dichotomous variable equal to 1 if the proportion of shares held by the largest shareholder exceeds 50\% and 0 otherwise; Inst_OWN: Institutional Ownership, measured by the proportion of shares held by institutional investors; Man_OWN: The Managerial Ownership, measured by the proportion of shares owned by managers; Board_SIZE: Size of board's directors, measured by the total number of board members; Bord_IND: Proportion of Independent Directors, measured by the number of independent non-executive directors to total number of board members; DUA: CEO Duality, measured by a dichotomous variable equal to 0 if the firm i is separated between the role of CEO and Chairman, and 1 otherwise; Audit_IND: Audit Committee Composition, measured by the number of directors on the audit committee; Audi_EXP: Audit Committee Expertise, measured by a dichotomous variable that equals one when the audit committee has at least one director with financial expertise and 0 otherwise; LEV: Financial leverage, measured by the total debt to total assets.; Firm_SIZE: Firm size, measured by the natural logarithm of total assets at the fiscal year-end; BIG4: External audit quality, measured by a dichotomous variable that equals one when the firm is audited by a large auditor and 0 otherwise; SOX: Financial Security Act, measured by a dichotomous variable that equals to 1 if the year is after 2005, 0 otherwise Author (Own elaboration).

Table 6 focuses on the financial security law in Tunisia, introduced in 2005 and implemented in 2006 which aims to improve the integrity of financial reporting. This law has introduced some reforms that increase the efficiency of the corporate governance, including the creation of a permanent audit committee within each listed company. This table examine if the transition from the application of this law affects the BTD.

The result of the table shows that SOX variable for the period after the financial security law is not significant. Thus, ABTD are not affected by this law. The coefficients on the variables Audit_IND becomes significant after this law. This may be due to the creation of the Audit Committee since that date. Auditor independence becomes an effective mechanism in the control of managerial discretions. However, Audi_EXP becomes not significant. This can be analyzed by the fact that the strength of the relationship between ABTD and financial experience of the audit committee weakens over the years after the SOX (Ghosh et al, 2010). The impact of the auditors experience became significantly lower in the years after the law.

In addition, the table shows the results of variables Audit_IND and Audi_EXP have a negative coefficient while the coefficients of the variables Audit_IND *SOX and Audi_EXP *SOX are positive. This change in sign is 
explained by Ghosh et al (2010) that the interaction terms are used to measure the marginal effects of the board of directors and the audit committee on ABTD for the years following the law on financial security.

\section{Conclusion}

This study examines whether book-tax differences (BTD) are associated with corporate governance mechanisms. We investigate whether (1) ownership structure are associated with BTD, (2) board and audit committee characters affect earnings and tax management, and (3) managerial manipulation declined after financial security law in Tunisia. Based on a sample of 21 corporations listed on Tunisian stock market during the period 2003-2012, our study employs regression analysis to test the prediction that the governance attributes reduces the likelihood of earnings and tax aggressiveness. We find that the ownership structure is an important corporate governance mechanism that affects BTD. Indeed, the concentration of capital and institutional investors showed an impact on ABTD. Regarding the board of directors we found that only the percentage of outside directors negatively affects discretionary differences. The Audit Committee influences ABTD through the variable relating to the financial expertise of the committee. The latter has changed after the introduction of the variable relating to the law on financial security. This committee now affects managerial discretions through these outside directors. This finding is in line with previous studies that have shown that corporate governance affects managerial manipulation. These results, confirm that the BTD can be an effective means of detection result of the management and tax management.

Our study is subject to several limitations. First, the choice of our sample was explained by the availability of data, we realized that the publication of the various mechanisms of governance as suggested by the good governance of Tunisian companies guide is not as developed and available for all companies. This lack of availability of data has prevented us to introduce other variables related to governance mechanisms. A second limitation is that the total number of companies in our sample is fairly small. The findings contribute to the debate on whether corporate governance mechanisms are effective or not to detect managerial discretion in emerging economies and developing countries. The results could be useful for normalizing and legislators who want to improve the quality and credibility of financial reporting and tax reporting. Future research into corporate governance and BTD should examine several matters. We propose to extend the study by taking into account other variables such as psychological factors that may explain the tendency of the manager to manipulate the results. Similarly, the executive compensation may be an element that must be considered. We have not been able to introduce them for reasons of data availability

\section{References}

Abaoub, E., \& Ben Amar, A. (2008). Les transferts de richesse des parties prenantes vers les actionnaires dans le cadre de la gestion du résultat. La Revue Comptable et Financière, 1, 3-27.

Abbott, L. J., Parker, S., \& Peters, G. F. (2000). The Effectiveness of Blue Ribbon Committee Recommendations in Mitigating Financial Misstatements: An Empirical Study. Working paper, University of Memphis.

Abed, S., Al-Attar, A., \& Suwaidan, M. (2012). Corporate Governance and Earnings Management: Jordanian Evidence. International Business Research, 5(1), 216-225. http://dx.doi.org/10.5539/ibr.v5n1p216

Alexandre, H., \& Paquerot, M. (2000). Efficacité des structures de contrôle et enracinement des dirigeants. Finance Contrôle Stratégie, 3(2), 5-29.

Aliani, K., \& Zarai, M. A. (2012). The board of directors and corporate tax planning: Empirical Evidence from Tunisia. International Journal of Accounting and Financial Reporting, 2(2), 142-157. http://dx.doi.org/10.5296/ijafr.v2i2.2525

Alves, S. (2012). Ownership Structure and Earnings Management: Evidence from Portugal. Australasian Accounting, Business and Finance Journal, 6(1), 57-74. http://dx.doi.org/10.1108/19852511111173103

Armstrong, C. S., Blouin, J. L., Jagolinzer, A. D., \& Larcker, D. F. (2014). Corporate Governance, Incentives, and Tax Avoidance. Working paper, The Wharton School. http://dx.doi.org/10.2139/ssrn

Badertscher, B. A., Katz, S. P., \& Rego, S. O. (2013). The Separation of Ownership and Control and Its Impact on Corporate Tax Avoidance. Working paper, University of Notre Dame. http://dx.doi.org/10.1016/j.jacceco.2013.08.005

Beasley, M. (1996). An empirical analysis of the relation between the board of director composition and financial statement fraud. The Accounting Review, 71, 443-465. http://dx.doi.org/10.1177/0149206315579510

Bédard, J., Marrakchi, S. C., \& Courteau, L. (2004). The effect of audit committee expertise, independence, and activity on aggressive earnings management. Auditing: A Journal of Practice \& Theory, 23(2), 13-35. 
http://dx.doi.org/10.2308/aud.2004.23.2.13

Ben Amar, A., \& Abaoub, E. (2010). Earnings management thresholds: The case in tunisia. Asian Academy of Management Journal of Accounting and Finance, 6(2), 35-56.

Beneish, M. (1997). Detecting GAAP violation: Implications for assessing earnings management among firms with extreme financial performance. Journal of Accounting and Public Policy, 16, 271-309. http://dx.doi.org/10.1016/S0278-4254(97)00023-9

Berle, A. A., \& Means, G. (1932). The Modern Corporation and the Private Property. New York: Mc Millan.

Blaylock, B., Shevlin, T., \& Wilson, R. (2012). Tax avoidance, large positive book-tax differences, and earnings persistence. The Accounting Review, 87, 91-120. http://dx.doi.org/10.2308/accr-10158

Boubraki, N., Cosset, J., \& Guedhami, O. (2005). Post-privatization corporate governance: The role of ownership structure and investor protection. Journal of Financial Economics, 76(2), 369-399. http://dx.doi.org/10.1016/j.jfineco.2004.05.003

Bowen, R., Rajgopal, S., \& Venkatachalam, M. (2008). Accounting discretion, corporate governance, and firm performance. Contemporary. Accounting Research, 25, 310-405. http://dx.doi.org/10.1506/car.25.2.3

Bryan, D., Liu, M., \& Tiras, S. (2004). The influence of independent and effective audit committees on earnings quality. Working Paper, SSRN. http://dx.doi.org/10.2139/ssrn.488082

Carecello, J. V., Hermanson, D. R., \& Ye, Z. S. (2006). Corporate Governance Research in Accounting and Auditing: Insights, Practice Implications, and Future Research Directions. Auditing: A Journal of Practice \& Theory, 30(3), 1-31. http://dx.doi.org/10.2308/ajpt-10112

Chen, L. H., Dhaliwal, D. S., \& Trombley, M. A. (2012). Consistency of Book-Tax Differences and Information Content of Earnings. The Journal of American Taxation Association, 34(2), 93-116. http://dx.doi.org/10.2308/atax-50174

Cheng, C. A., \& Li, S. (2014). Does income smoothing improve earnings informativeness? A comparison between the US and China markets. China Accounting and Finance Review, 16(2), 128-147. http://dx.doi.org/10.7603/s40570-014-0010-6

Choi, S. K., \& Seo, J. W. (2008). Institutional Ownership and Accounting Transparency. Asia-Pacific Journal of Financial Studies, 37(4), 627-673.

Chung, R., Firth, M., \& Kim, J. B. (2002). Institutional monitoring and opportunistic earnings management. Journal of Corporate Finance, 8, 29-48. http://dx.doi.org/10.7603/s40570-014-0010-6

Comprix, J., Graham, R., \& Moore, J. (2011). Empirical Evidence on the Impact of Book-Tax Differences on Divergence of Opinion among Investors. Journal of the American Taxation Association, 33(1), 51-78. http://dx.doi.org/10.2308/jata.2011.33.1.51

Dechow, P., Sloan, R., \& Sweeney, A. (1996). Causes and consequences of earnings manipulation: An analysis of firms subject to enforcement actions by the SEC. Contemporary accounting research, 13(1), 1-36. http://dx.doi.org/10.1111/j.1911-3846.1996.tb00489.x

Desai, M. A., \& Dharmapala, D. (2006). Corporate tax avoidance and high powered incentives. Journal of Financial Economics, 79, 145-179. http://dx.doi.org/10.3386/w10471

Dhaliwal, D. S., Lee, H. S. G., \& Pincus, M. (2009). Book-Tax Differences, Uncertainty about Information Quality, and Cost of Capital. Working Paper, University of Arizona. http://dx.doi.org/10.2139/ssrn.1127956

Dimitropoulos, P. E., \& Asteriou, D. (2010). The effect of board composition on the informativeness and quality of annual earnings: Empirical evidence from Greece. Research in International Business and Finance, 24, 190-205. http://dx.doi.org/10.1016/j.ribaf.2009.12.001

Donohoe, M. P., \& McGill, G. A. (2010). The Effects of Increased Book-Tax Differences Tax Returns Disclosure on Firm Valuation and Behavior. Journal of American Taxation Association, 33(2), 35-65. http://dx.doi.org/10.2308/atax-10056

Dridi, W., \& Boubaker, A. (2015). The difference between the accounting result and taxable income in detecting earnings management and tax management: The Tunisian case. International Journal of Business and Management, forthcoming. http://dx.doi.org/10.5539/ijbm.v10n7p131

Fama, E. F., \& Jensen, M. C. (1983). Separation of ownership and control. Journal of Law and Economics, 26, 301-325. 
Fan, J., \& Wong, T. J. (2002). Corporate ownership structure and the informativeness of accounting earnings in East Asia. Journal of Accounting and Economics, 33, 401-425. http://dx.doi.org/10.2139/ssrn.243226

Firth, M., Fung, P. Y. P., \& Ruin, O. (2007). Ownership, two-tier board structure, and the informativeness of earnings: Evidence from China. Journal of Accounting and Public Policy, 26, 463-49. http://dx.doi.org/10.1016/j.jaccpubpol.2007.05.004

Gabrielsen, G., Gramilch, J. D., \& Plenborg, T. (2002). Managerial Ownership, Information Content of Earning, and Discretionary Accruals in a non US Setting. Journal of Business Finance and Accounting, 29(7), 967-988. http://dx.doi.org/10.1111/1468-5957.00457

Geiger, M., \& North, D. (2011). Do CEOs and principal Financial officers take a "bath" separately or together?: An investigation of discretionary accruals surrounding appointments of news CEOs and PFOs. (Appointment of Principal Financial Officers). Academy of Accounting and Financial Studies Journal, 15(1), 1-32.

Ghosh, A., Marra, A., \& Moon, D. (2010). Corporate Boards, Audit Committees, and Earnings Management: Pre- and Post-SOX Evidence. Journal of Business Finance \& Accounting, 37(9-10), 1145-1176. http://dx.doi.org/10.1111/j.1468-5957.2010.02218.x

Goh, W., Lee, J., Lim, C., \& Shevlin, J. (2013). The Effect of Corporate Tax Avoidance on the Cost of Equity. Singapore Management University School of Accountancy Research Paper, (2014-11). http://dx.doi.org/10.2139/ssrn.2237742

Gonzalez, J. S., \& Garcia-Meca, E. (2013). Does Corporate Governance Influence Earnings Management in Latin American Markets? Journal of Business Ethics, 121(3), 419-440. http://dx.doi.org/10.1007/s10551-031-1700-8

Gupta, S. (1995). Determinants of the choice between partial and comprehensive income tax allocation: The case of the domestic international sales corporation. The Accounting Review, 70(3), 489-511. http://www.jstor.org/stable/248535

Hanlon, M. (2005). The persistence and pricing of earnings, accruals and cash flows when firms have large book-tax differences. The Accounting Review, 80, 137-166. http://dx.doi.org/10.2308/accr.2005.80.1.137

Hanlon, M., Krishnan, G. V., \& Mills L. F. (2012). Audit Fees and Book-Tax Differences. Journal of American Taxation Association, 34(1), 55-86. http://dx.doi.org/10.2308/atax-10184

Hsu, G., \& Koh, P. (2005). Does the presence of institutional investors influence accruals management? $\begin{array}{lllll}\text { Evidence from } & \text { Australia. } & \text { Corporate } & \text { Governance, } & 13(3),\end{array}$ http://dx.doi.org/10.1111/j.1467-8683.2005.00472.x

Huang, H. W., \& Thiruvadi, S. (2010). Audit Committee Characteristics and Corporate Fraud. International Journal of Public Information Systems, 6(1), 71-82.

Jalali, M., Jalali, F., Moridi, F., Garshasbi, A., \& Foroodi, M. (2013). The Impact of The Board of Directors'Structure on Tax Avoidance In The Companies Listed in Tehran Stock Exchange. International Research Journal of Applied and Basic Sciences, 4(9), 2526-2531.

Jeanjean, T. (2001). Incitations et contraintes à la gestion du résultat. Comptabilité Contrôle Audit, 7(1), 61-76.

Jensen, M. C. (1993). The Modern Industrial Revolution, Exit, and the Failure of the Internal Control Systems. Journal of Finance, 48, 831-880. http://dx.doi.org/10.1111/j.1540-6261.1993.tb04022.x

Jensen, M., \& Meckling, W. (1976). Theory of the firm: Management behavior, agency costs, and ownership structure. Journal of Financial Economics, 3, 305-360. http://dx.doi.org/10.1016/0304-405X(76)90026-x

Joos, P., Pratt, J., \& Young, D. (2000). Book-tax differences and the value relevance of earnings. Working paper, Massachusetts Institute of Technology, Indiana University, and INSEAD.

Khan, A., \& Mather, P. (2013). The value of executive director share ownership and discretionary accruals. Accounting Research Journal, 26(1), 35-55. http://dx.doi.org/10.1108/ARJ-0.-2012-0011

Klein, A. (2002). Audit committees, board of directors characteristics and earnings management. Journal of Accounting and Economics, 33, 375-400. http://dx.doi.org/10.2139/ssrn.246674

Koh, P. (2003). On the Association between institutional ownership and aggressive corporate earnings management in Australia. The British Accounting Review, 35(2), 105-128. http://ssrn.com/abstract=424841

Lanis, R., \& Richardson, G. (2011). The effect of board of director composition on corporate tax aggressiveness. 
The Journal of Accounting and Public Policy, 30, 50-70. http://dx.doi.org/10.1016/j.jaccpubpol.2010.09.003

Lasalle, R., Scott, K. J., \& Rohit, J. (1993). The Association Between Executive Succession and Discretionary Accounting Changes: Earnings Management or Different Perspectives? Journal of Business Finance \& Accounting, 20(5), 653-671. http://dx.doi.org/10.1111/j.1468-5957.1993.tb00282.x

McMullen, D. S. (1996). Audit Committees Performance: An Investigation of consequences associated with audit committees. Auditing: A Journal of practice and theory, 15(1), 87-103.

Mills, L., \& Newberry, K. (2001). The Influence of Tax and Non-Tax Costs on Book-Tax Reporting Differences: Public and Private Firms. Journal of the American Taxation Association, 23, 1-19. http://dx.doi.org/10.2308/jata.2001.23.1.1

Minnick, K., \& Noga, T. (2010). Do corporate governance characteristics influence tax management? Journal of Corporate Finance, 16, 703-718. http://dx.doi.org/10.1016/j.jcorpfin.2010.08.005

Nejad, H. S., Zeynali, S., \& Alavi, S. S. (2013). Investigation of income smoothing at the companies listed on the stock exchange by the using index eckel (case study: Tehran stock exchange). Asian Journal of Management Sciences and Education, 2(2), 49-62.

Njah, M., \& Jarboui, A. (2013). Institutional investors, corporate governance, and earnings management around merger: evidence from French absorbing firms. Journal of Economics, Finance and Administrative Science, 18, 89-96. http://dx.doi.org/10.1016/S2077-1886(13)70033-7

Peasnell, K. V., Pope, P. F., \& Young, S. (2005). Board monitoring and earnings management: Do outside directors influence abnormal accruals? Journal of Business Finance and Accounting, 32(7-8), 1311-1346. http://dx.doi.org/10.2139/ssrn.249557

Pourciau, E. G. (1993). Earnings management and nonroutine executive changes. Journal of Accounting an Econimics, 16, 317-336. http://dx.doi.org/10.1016/0165-4101(93)90015-8

Rajgopal, S., Venkatachalam, M., \& Jiambalvo, J. (1999). Is Institutional Ownership Associated with Earnings Management and the Extent to which Stock Prices Reflect Future Earnings? Working paper, University of Washington. http://dx.doi.org/10.2139/ssrn.163433

Richardson, G., Taylor, G., \& Lanis, R. (2013). The impact of board of director oversight characteristics on corporate tax aggressiveness: An empirical analysis. The Journal of Accounting and Public Policy, 32, 68-88. http://dx.doi.org/10.1016/j.jaccpubpol.2013.02.004

Robinson, J. R., Xue, Y., \& Zhang, M. H. (2012). Tax planning and financial expertise in the audit committee. Working paper, University of Texas at Austin. http://dx.doi.org/10.2139/ssrn.2146003

Shabou, R. (2000). Nature des détenteurs de blocs de contrôle, mécanismes contrôle et performance financière des entreprises tunisiennes. Working Paper, Université de Sfax.

Shabou, R., \& Boulila, T. N. (2002). Les déterminants de la comptabilité créative: Etude empirique dans le contexte des entreprises tunisiennes. Comptabilité, Contrôle, Audit, 8(1), 5-24. http://dx.doi.org/10.3917/cca.081.0005

Shleifer, A., \& Vishny, R. W. (1997). A Survey of Corporate Governance. Journal of Finance, 52, 737-783. http://dx.doi.org/10.1111/j.1540-6261.1997.tb04820.x

Stolowy, H., \& Breton, G. (2003). La gestion des données comptables : une revue de la littérature. Comptabilité, Contrôle, Audit, 9(1), 125-152. http://dx.doi.org/10.3917/cca.091.0125

Tang, T., \& Firth, M. (2011). Can Book-Tax Differences Capture Earnings Management and Tax Management? Empirical Evidence from China. The International Journal of Accounting, 46(2), 175-204. http://dx.doi.org/10.1016/j.intacc.2011.04.005

Wan, N., \& Wan, H. (2009). The impact of family-firm structure and board composition on corporate transparency: Evidence based on segment disclosures in Malaysia. The International Journal of Accounting, 44, 313-333. http://dx.doi.org/10.1016/j.intacc.2009.09.003

Warfield, T., Wild, J., \& Wild, K. (1995). Managerial ownership, accounting choices, and informativeness of $\begin{array}{lllll}\text { earnings. Journal of Accounting and Economics, } & \text { 20, }\end{array}$ http://dx.doi.org/10.1016/0165-4101(94)00393-J

Waweru, N. M., \& Riro, G. K. (2013). Corporate Governance, Firm Characteristics and Earnings Management in an Emerging Economy. The Journal of Applied Management Accounting Research, 11(1), 43-64. 
Wooldridge, J. (2002). Econometric Analysis of Cross Section and Panel Data. Cambridge: The MIT Press. http://dx.doi.org/10.1111/j.1368-423X.2011.00351.x

Xie, B., Davidson, W. N., \& DaDalt, P. J. (2003). Earnings management and corporate governance: The role of the board and the audit committee. Journal of Corporate Finance, 9, 295-316. http://dx.doi.org/10.1016/S0929-1199(02)00006-8

Yang, J. S., \& Krishnan, J. (2005). Audit Committees and Quarterly Earnings Management. Working paper, University of Minnesota Duluth, SSRN. http://dx.doi.org/10.1111/j.1099-1123.2005.00278.x

Yang, W. S., Chun, L. S., \& Ramadili, S. M. (2009). The Effect of Board Structure and Institutional Ownership Structure on Earnings Management. International Journal of Economics and Management, 3(2), 332-353.

Yeo, G., Tan, P., \& Chen, S. (2002). Corporate Ownership Structure and the Informativeness of Earnings. Journal of Business Finance and Accounting, 29(7), 1023-1046. http://dx.doi.org/10.1111/1468-5957.00460

Yermack, D. (1996). Higher market valuation of companies with a small board of directors. Journal of Financial Economics, 40, 185-211. http://dx.doi.org/10.1016/0304-405X(95)00844-5

Zemzem, A., \& Ftouhi, K. (2013). The Effects of Board of Directors' Characteristics on Tax Aggressiveness. Research Journal of Finance and Accounting, 4(4), 140-148.

\section{Copyrights}

Copyright for this article is retained by the author(s), with first publication rights granted to the journal.

This is an open-access article distributed under the terms and conditions of the Creative Commons Attribution license (http://creativecommons.org/licenses/by/3.0/). 